\title{
ANALISA SIFAT FISIKO KIMIA DAN ANTI BAKTERI ASAP CAIR CANGKANG KELAPA SAWIT UNTUK PENGAWET PANGAN
}

\author{
Titiek Pujilestari \\ Balai Riset dan Standardisasi industri Samarinda
}

\begin{abstract}
Physico-chemical properties and anti-bacterial agent of liquid smoke palm shell for food preservation has been performed. The liquid smoke was made by dry distillation method, and then partially purified by precipitationfiltration and distillation. Chemical components were assayed using GC-MS and anti bacteria capacity was assayed using agar diffusion method. Results showed that differences in purification treatment leads to a different physico-chemical properties and anti bacterial capacity of liquid smoke produced. Partially purified of pure liquid smoke produced followed by distillation process have characteristic of clear, impurities of $0.09 \%$ and $\mathrm{pH}$ of 3.07. Dominant chemical compounds found in the various treatments were cyclopentanone, 2-furancarboxaldehyde, acetic acid, and acid propanoate. Partial purified liquid smoke by precipitation-filtration showed inhibition on bacterial growth of $E$. Coli and $S$. aureus, but could not inhibit the growth of Salmonella, whereas partial purified of liquid smoke by distillation did not have inhibitory effect on the growth of $E$. Coli, $S$ aureus and Salmonella.
\end{abstract}

Keyword: Palm shell, liquid smoke, chemical campound, anti-bacterial

\section{PENDAHULUAN}

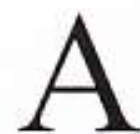

sap cair merupakan suatu campuran larutan dan dispersi koloid dari uap asap kayu dalam air yang diperoleh dari hasil pirolisa, mempunyai warna kuning sampai coklat kehitaman berbau sengak (asap) dan mengandung senyawa yang sangat kompleks, terdapat sekitar 200 senyawa yang dikelompokkan pada senyawa asam, fenol dan alkohol serta merupakan komponen penting dalam pengembang cita rasa, warna dan pengendalian mikroba. Asap cair diperoleh bersamaan dengan proses pembuatan arang (karbonisasi), timbulnya asap akibat pembakaran yang tidak sempurna dialirkan melalui pipa kondensasi sehingga akan terjadi tetesan-tetesan cairan yang disebut asap cair. Asap cair juga dapat diperoleh dengan cara destilasi kering dari bahan berlignoselulose antara lain tempurung kelapa, kayu dan cangkang kelapa sawit pada suhu $200-400^{\circ} \mathrm{C}$. Cairan/destilat yang diperoleh berwarna coklat tua dan masih tercampur dengan senyawa- senyawa kimia yang tidak diinginkan seperti tar dan senyawa karsinogen lainnya.

Asap cair dari bahan berlignoselulose memiliki kandungan sejumlah senyawa yang terbentuk oleh pirolisis dari selulose, hemiselulose dan lignin. Kelompok-kelompok penting dari 
senyawa tersebut meliputi fenol, karbonil, asam, furan dan alkohol. Fenol mempunyai sifat anti bakteri dan anti oksidan. Dua senyawa utama dalam asap cair yang mempunyai efek bakteriostatik adalah fenol dan asamasam organik yang dalam kombinasinya kedua senyawa tersebut bekerja sama secara efektif untuk mengontrol pertumbuhan mikroba.

Penggunaan asap cair sebagai pengawet pangan mempunyai beberapa keuntungan antara lain warna dan cita rasa produk pangan dapat dikendalikan, dimungkinkan diperoleh keseragam an mutu produk pada waktu yang berbeda. Konsentrasi pemakaiannya cukup sedikit, dan aplikasi penggunaannya cukup mudah serta cepat, yaitu dengan cara merendam atau menyemprotkan serta mencampurkan langsung kedalam bahan pangan.

Aktifitas produksi pabrik minyak kelapa sawit menghasilkan limbah dalam jumlah yang cukup besar, baik limbah padat maupun limbah cair. Limbah padat pabrik kelapa sawit dengan kapasitas 100 ribu ton tandan buah segar (TBS) pertahun akan menghasilkan sekitar 6 ribu ton cangkang, 12 ribu ton serabut dan 23 ribu ton tandan buah kosong (Marpaung: DS. 2009).

Asap cair tempurung kelapa produksi Kulonprogo telah mendapatkan sertifikat aman sebagai bahan pengawet pangan dari Kanada dan Malaysia (Arviza $Y$ dan Amin S. 2006). Cangkang kelapa sawit memiliki sifat fisik yang mirip dengan tempurung kelapa yaitu padat dan keras. Diduga asap cair cangkang kelapa sawit juga memiliki sifat yang mirip dengan asap cair tempurung kelapa, sehingga aman dan dapat difungsikan sebagai pengawet pangan. Tujuan dari penelitian ini adalah untuk mengetahui sifat fisiko kimia dan anti bakteri asap cair cangkang kelapa sawit dalam kaitannya sebagai pengawet pangan.

\section{BAHAN DAN METODA}

\section{Bahan dan Peralatan}

Bahan baku yang digunakan untuk pembuatan asap cair berupa cangkang kelapa sawit, diambil dari pabrik kelapa sawit yang berlokasi di Kabupaten Penajam Paser Utara, Propinsi Kalimantan Timur. Bahan penolong untuk pembuatan asap cair berupa kayu bakar, minyak tanah dan bahan kimia untuk analisis sifat fisik, kimia dan mikrobiologi asap cair.

Peralatan yang digunakan untuk penelitian terdiri dari reaktor karbonisasi yang dilengkapi dengan pendingin dan tungku pembakaran, Gas Chromatography-Mass Spectros copy (GC-MS) untuk uji senyawa kimia, timbangan, oven, jerigen plastik, selang dan sejumlah peralatan laboratorium untuk analisis asap cair.

Metode

Asap cair dibuat dari bahan baku cangkang kelapa sawit dengan cara distilasi kering, sebagai berikut, cangkang kelapa sawit yang digunakan adalah yang telah kering udara, kemudian dimasukkan ke dalam reaktor pirolisa yaitu suatu tungku pembakaran yang dilengkapi dengan cerobong penangkap asap dan pipa untuk pengaliran asap yang berpendingin, selanjutnya dibagian ujung pipa pendingin di tempatkan wadah untuk penampung kondensat. Berikutnya reaktor ditutup rapat-rapat agar asap yang terjadi seluruhnya keluar melalaui saluran yang telah disediakan yaitu pipa pengaliran yang berpendingin. Adanya kebocoran dikawatirkan akan mempengaruhi jumlah dan kandungan senyawa kimia asap cair yang diperoleh.

Setelah itu dilakukan pemanasan pada bagian bawah/dasar reaktor dengan menggunakan bahan bakar kayu, suhu pirolisis dipertahankan pada kisaran $250-400^{\circ} \mathrm{C}$. Pemanasan dihentikan jika sudah tidak ada lagi cairan dari pipa yang menetes. Asap cair yang diperoleh dimurnikan untuk menghilangkan kotoran dan tar.

Pemurnian dilakukan dengan dua cara yaitu pengendapan-diikuti penyaringan dan distilasi /penyuling an. 
Pemurnian dengan pengendapan diikuti penyaringan dikerjakan sebagai berikut asap cair dibiarkan selama 24 jam, endapan yang terbentuk dipisahkan, kemudian cairan disaring dengan menggunakan kertas saring. Pemurnian dengan distilasi dikerjakan sebagai berikut; asap cair disuling pada suhu $103^{\prime \prime} \pm 2^{*}$ C, penyulingan dihentikan sampai tertinggal tar dan kotorannya. Distilat yang diperoleh merupakan asap cair murni.

Terhadap asap cair baik yang tidak dimurnikan maupun yang dimurnikan, semuanya dilakukan analisa mengenai sifat fisik, kimiawi dan anti mikroba. Pengujian sifat fisik meliputi kadar air, kadar kotoran, berat jenis dan $\mathrm{pH}$. Pengujian kimia asap cair dilakukan dengan alat GC-MS untuk mengetahui kandungan senyawa kimia dominan. Pengujian anti mikroba menggunakan metoda difusi agar, mikroba yang dipilih adalah bakteri E.Coli, $S$ Aureus dan Salmonela. Ketiga mikroba tersebut merupakan mikroba patogen yang sering mencemari dan sebagian merusak bahan pangan.

\section{HASIL DAN PEMBAHASAN}

Asap cair hasil destilasi kering dari cangkang kelapa sawit mempunyai warna coklat kehitaman, mengandung kotoran, tar dan char sehingga perlu pemurnian untuk memperoleh warna yang lebih terang, bersih dan bebas kotoran.

Setelah dimurnikan dengan pengendapan-penyaringan, asap cair berwarna kuning, dan setelah dimurnikan dengan penyulingan berwarna kuning muda.

Terhadap tiga contoh asap cair cangkang kelapa sawit yaitu yang belum dimurnikan dan yang telah mengalami pemurnian; baik dengan cara pengendapan-penyaringan maupun penyulingan, dilakukan pengujian terhadap sifat fisik, senyawa kimia dan anti mikroba. Pengujian anti mikroba ditujukan untuk mengetahui kemampuan senyawa fungsional sebagai pengawet pangan.

\section{Sifat Fisik Asap Cair}

Pengujian sifat fisik asap cair cangkang kelapa sawit dari tiga contoh meliputi kadar air, kadar kotoran,berat jenis dan $\mathrm{pH}$ seperti disajikan pada Tabel 1.

Dari pirolisis cangkang kelapa sawit ternyata diperoleh kadar air $82,24 \%$ dan setelah penyaringan kadar air tidak mengalami perubahan yaitu sebesar $82,51 \%$ dan setelah penyulingan kadar air mengalami peningkatan menjadi $89,67 \%$. Peningkatan ini dipengaruhi suhu proses distilasi yaitu $103 \pm 2^{\circ} \mathrm{C}$ sehingga semua air terikut dalam asap cair. Kadar air asap cair antara lain sangat dipengaruhi oleh kadar air awal bahan baku yang digunakan, semakin kering bahan baku maka akan dihasilkan asap cair dengan kadar air yang rendah. Menurut Yatagai (2004), karakteristik asap cair adalah memiliki kadar air $80 \%$ sampai $90 \%$ dan kandungan bahan organik $10 \%$ sampai $20 \%$ serta memiliki derajad keasaman tinggi yaitu $\mathrm{pH} 1,5$ 3,7 .

Tabel 1: Sifat Fisik Asap Cair Cangkang Kelapa Sawit

\begin{tabular}{|c|l|c|c|c|c|}
\hline No & \multicolumn{1}{|c|}{ Perlakuan Asap Cair } & $\begin{array}{c}\text { Kadar Air } \\
(\%)\end{array}$ & $\begin{array}{c}\text { Kadar } \\
\text { Kotoran }(\%)\end{array}$ & $\begin{array}{c}\text { Berat } \\
\text { Jenis }\end{array}$ & $\mathrm{pH}$ \\
\hline 1 & Tanpa Perlakuan & 82,24 & 0,17 & 0,9969 & 3,40 \\
\hline 2 & Pengendapan - Penyaringan & 82,51 & 0,12 & 0,9874 & 3,40 \\
\hline 3 & Penyulingan & 89,67 & 0,09 & 0,9886 & 3,07 \\
\hline
\end{tabular}

Kadar kotoran asap cair cangkang kelapa sawit dan yang telah mengalami pemurnian dengan pengendapan-penyaringan serta penyulingan ternyata menunjukkan hasil yang berbeda ( Tabel 1). Kadar kotoran asap cair sebelum perlakuan pemisahan 
$0,17 \%$ mempunyai warna coklat kehitaman, namun setelah perlakuan penyaringan terjadi penurunan menjadi $0,12 \%$ dengan warna cairan kuning. Dengan adanya penyaringan maka partikel-partikel padat yang tidak larut air dapat tertahan di filter pada proses penyaringan sehingga dapat menurunkan kadar kotoran dan mempengaruhi warna sehingga menjadi lebih cerah. Penyulingan dapat menurunkan kadar kotoran asap cair dari $0,17 \%$ menjadi $0,09 \%$ dan warna asap cair menjadi jernih, bersih dan tidak terlihat adanya kotoran yang melayang.

Berat jenis dari tiga sampel asap cair cangkang kelapa sawit memberikan hasil yang rata-ratanya berkisar antara 0,9874 - 0,9969, hal ini berarti berat cairan pada volume tertentu pada ketiga jenis asap cair tidak menunjukan perbedaan yang signifikan. Menurut Pujilestari T (2007) berat jenis dari asap cair kayu galam yang telah mengalami pemisahan kotoran dengan pasir zeolit, penyulingan dan pengendapan penyaringan memberikan hasil yang tidak jauh berbeda yaitu berkisar 0,980 $-0,988$.

Nilai $\mathrm{pH}$ asap cair cangkang kelapa sawit yang belum dimurnikan dan yang telah dimurnikan dengan pengendapan-penyaringan serta penyulingan bervariasi $3,07-3,40$. Nilai $\mathrm{pH}$ dengan perlakuan pengendapanpenyaringan tidak berbeda dengan nilai $\mathrm{pH}$ pada asap cair tanpa perlakuan. namun asap cair yang dimurnikan dengan penyulingan $\mathrm{pH}$ nya paling rendah yaitu 3,07. Asap cair setelah mengalami proses penyulingan terjadi perubahan kandungan senyawa dan kandungan asam asetatnya menurun cukup signifikan seperti pada Tabel 2 .

Menurut Yatagai (2004), bahwa $\mathrm{pH}$ asap cair yang baik berkisar antara $1,5-3,7$, dengan demikian asap cair cangkang kelapa sawit dapat dimanfaatkan untuk berbagai keperluan pangan. Pada kondisi $\mathrm{pH}$ rendah mikroba yang berspora tidak dapat hidup dan berkembang biak sehingga dapat berperan menghambat pertumbuhan mikroba pembusuk.

\section{Senyawa Kimia Asap Cair}

Asap cair cangkang kelapa sawit yang tidak dimurnikan dan yang dimurnikan dengan pengendapan-penyaringan, serta penyulingan dilakukan pengujian terhadap kandungan senyawa kimia dominan dengan menggunakan alat Gas Chromatography Mass Spectro photometri (GC-MS) hasil ujinya disajikan pada Tabel 2.

Pada Tabel 2 menunjukkan bahwa asap cair dari ketiga jenis perlakuan memberikan hasil senyawa kimia yang berbeda-beda, namun dapat dikelompokkan dalam golongan alkohol, asam, keton, dan aldehyde. Persen area tertinggi pada asap cair tanpa perlakuan adalah isobutyl alkohol sedang pada asap cair yang dimurnikan dengan pengendapan-penyaringan dan pe nyulingan adalah 1,2- Ethanediol dengan persen area masing-masing 72,17 dan 83,53 . 
Tabel 2: Senyawa Kimia Dominan Asap Cair Cangkang Kelapa Sawi

\begin{tabular}{|c|l|c|c|c|}
\hline \multirow{2}{*}{ No. } & \multirow{2}{*}{ Jenis Senyawa } & \multicolumn{3}{|c|}{ \% Area Senyawa Dominan } \\
\cline { 3 - 5 } 1 & A & B & C \\
\hline 2 & 1,2- Ethanidiol & - & 72,17 & 83,53 \\
3 & Isobuthyl Alkohol & 58,03 & - & - \\
4 & Asam asetat & 26,52 & 11,50 & 3,78 \\
5 & Asam propanoat & - & - & 3,23 \\
6 & Cyclopentanone & 2,01 & 1,90 & 0,31 \\
7 & 2-Furancarboxaldehyde & 0,70 & 0,88 & 0,99 \\
8 & Fenol & 6,68 & 6,11 & 8,16 \\
9 & Alpha-cholesta-722-diene & 4,55 & - & - \\
10 & Furan, Tetrahydrofuran & 0,68 & - & - \\
11 & 2.3 Butanedione & 0,84 & - & - \\
12 & Asam propanoat methyl ester & - & 5,29 & - \\
13 & 2-3 Pentanedion & - & 1,28 & - \\
\hline
\end{tabular}

Keterangan :

$A=$ Asap cair tanpa pemumian.

$B=$ Asap cair murni perlakuan pengendapan-penyaringan

$C=$ Asap cair mumi perlakuan penyulingan.

Hal ini sesuai pendapat (Maga, 1987 dalam Hadiwiyoto, dkk, 2000) bahwa pada pembakaran bahan berlignoselulose maka hemiselulose akan mengalami dekomposisi menjadi furan dan turunannya. Pirolisis lignin akan menghasilkan guaiakol, 4-metil guaiakol, 4-etil guaiakol dan asetovanilon; pirolisis selulose akan menghasilkan char, tar, levoglukos an, 1,6 anhidro-b-D-glukofuran dan material yang mudah menalami hidrolisis. Selanjutnya Girard (1992) menyatakan bahwa pirolisis selulose akan menghasilkan golongan furan dan fenol; pirolisis lignin akan menghasilkan metal ester pirogalol dan tar yang merupakan campuran guaiakol, kresol dan fenol.

Senyawa kimia dominan yang keberadaannya selalu ada pada ketiga asap cair adalah asam asetat, asam propanoat, cyclopentanone, 2furancarboxaldehyde. Asam asetat pada asap cair tanpa pemurnian paling tinggi kemudian semakin menurun pada perlakuan pengendapan-penyaringan dan te rendah pada penyulingan. Asam asetat mempunyai sifat karakteristik diantaranya merupakan cairan tak berwarna, berbau tajam dan larut dalam air, alkohol, gliserol, eter, tidak larut dalam karbon disulfit, berfungsi dalam pembuat asetat anhidrid, selulose asetat, bahan

pembuat plastik, obat-obatan, pewarna insektisida dan sebagai tambahan makanan. Senyawa 2-furan karboksaldehide pada ketiga jenis asap cair hampir sama bervariasi sekitar 6,11 - $8,16 \%$. Senyawa ini merupakan cairan tidak berwarna, menjadi coklat kemerahan jika terkena sinar dan udara; larut dalam pelarut organik, dan dapat berfungsi sebagai fungisida ( Lewis. 1993).

Asap cair yang diperoleh dari proses pirolisa masih tercampur dengan partikel padat dan partikel cair yang mengandung berbagai senyawa organik dan anorganik yang dapat bersifat karsinogen sebagai contoh senyawa benzopirin. Benzopirin merupakan kelompok se nyawa polisiklis aromatik hidrokarbon (PAH) dengan lima cincin benzene. Senyawa ini sangat beracun dan bersifat karsinogen dan telah dinyatakan sebagai indikator kontaminan dalam makanan. Tingkat karsinogen dalam makanan yang diasap dipengaruhi antara lain metode atau cara pembuatan asap dan suhu pengasapan.

Hasil pengujian asap cair cangkang kelapa sawit dengan alat GCMS ternyata bahwa senyawa karsinogen 
dimaksud tidak terdeteksi keberadaannya. Golongan senyawa ini diduga sangat kecil kandungan nya. Di Jerman kadar maksimum benzopirin dalam bahan makanan yang diijinkan adalah 1 ppb (Tilgner, 1968 dalam Tranggono, 1996). Dengan perlakuan penyaringan dan pendinginan kondensat asap dapat dihasilkan $\mathrm{PAH}$ dengan konsentrasi yang lebih rendah tanpa mengganggu sifat flavour. Semua proses yang menyebabkan terpisahnya partikel-partikel asap yang besar (bentuk seperti jelaga) mengakibatkan penurunan jumlah benzopirin dan hidrokarbon polisiklis aromatik yang lainnya (Potthast, 1975 dalam Tranggono dkk, 1997 ). Karena kandungan benzopirin tidak terdeteksi maka asap cair cangkang kelapa sawit aman digunakan sebagai bahan pengawet pangan

Aktifitas Anti Bakteri

Hasil pengujian aktifitas anti bakteri asap cair cangkang kelapa sawit terhadap pertumbuhan $E$. Coli, Salmonela dan Staphylococus aureus; disajikan pada Tabel 1. Pengujian tersebut dilakukan pada asap cair yang tidak dimurnikan dan yang dimurnikan dengan perlakuan pengendapanpenyaringan dan per lakuan penyulingan. Daya hambat bakteri ditandai dengan diameter pembentukan zona bening pada petri.

Hasil pengujian menunjukkan bahwa asap cair yang tidak dimurnikan dan yang dimurnikan dengan pengendapan-penyaringan memiliki daya hambat terhadap pertumbuhan bakteri $E$. coli dan $S$. aureus karena memiliki daerah zona bening penghambatan sebesar $1,5 \mathrm{~cm}$, tetapi tidak ada penghambatan pada pertumbuhan Saimonela. Selanjutnya asap cair dengan pemurnian penyulingan tidak memiliki daya hambat terhadap ketiga pertumbuhan $E$.coli, S. aureus dan Salmonella. Menurut Herwig (1979) dalam Rahmi, N. (2008) bahwa suatu bahan memiliki daya hambat pertumbuhan mikoba sangat kuat bila diameter hambatnya $>20 \mathrm{~mm}$, kuat 10 -
$20 \mathrm{~mm}$, sedang $5-10 \mathrm{~mm}$ dan lemah $<5$ $\mathrm{mm}$. Oleh karena itu dapat dikatakan bahwa asap cair yang tidak dimurnikan dan yang dimurnikan dengan pengendapan-penyaringan memiliki daya hambat yang kuat terhadap pertumbuhan bakteri $E$. coli dan $S$. aureus

Bakteri E. coli dan Salmonella merupakan golongan bakteri gram negative yang dinding selnya memiliki lapisan peptidoglikan yang tipis tetapi mempunyai perbedaan pada metabolisme dan sifat fisiologis lainnya sehingga sensitivitas dan kemampuan resistensi antibakteri terhadap senyawa kimia tertentu juga berbeda.

Senyawa kimia dalam asap cair sangat berperan dalam penghambatan mikroba, terutama jenis fenol dan asam asetat. Asap cair cangkang tanpa pemurnian mengandung asam asetat $26,52 \%$ dan fenol $4,55 \%$, sedang pada asap cair dengan pemurnianpenyaringan mengandung asam asetat $11.50 \%$ dan dengan penyulingan me ngandung asam asetat sangat rendah yaitu $3,78 \%$. Semakin rendah kadar asam asetat semakin rendah pula penghambatan anti mikroba dan ternyata pada area $3,78 \%$ sudah tidak memiliki lagi daya penghambat an pertumbuhan mikroba.

$\mathrm{Hal}$ ini sesuai dengan pendapat Pszczola (1995) bahwa dua senyawa utama dalam asap cair yang diketahui mempunyai efek bakterisida/bakteriostatik adalah fenol dan asam-asam organik, kombinasi keduanya dapat bekerja secara efektif untuk mengontrol pertumbuhan mikrobia, Disamping itu fenol juga memiliki aktivitas antioksidan yang cukup besar.

Oleh karena asap cair cangkang kelapa sawit yang dimurnikan menggunakan proses penyulingan tidak dapat me ngendalikan pertumbuhan mikroba, maka asap cair ini tidak cocok untuk tujuan pengawetan pangan, namun demikian masih dapat digunakan dalam proses pengolahan pangan untuk tujuan penambah cita rasa. Sedangkan yang 
tidak dimurnikan dan yang dimurnikan melalui proses pengendapanpenyaringan dapat digunakan untuk tujuan pengawetan pangan, karena disamping dapat mengendalikan pertumbuhan mikroba, juga tidak ditemukan PAH yang berbahaya bagi kesehatan. Walaupun demikian untuk tujuan pengawetan pangan tetap disarankan menggunakan asap cair yang telah dimurnikan dengan proses pengendapan-penyaringan karena bersifat fisik lebih baik, apabila dibandingkan dengan yang tidak dimurnikan; sehingga tidak akan mempengaruhi penampilan bahan pangan yang diawetkan, bahkan diharapkan dapat memperbaikinya.

Dosis yang tepat untuk pengawetan pangan tergantung dari jenis bahan pangan yang akan diawetkan, waktu awet yang diharapkan serta warna, aroma dan citarasa yang dikehendaki.

Tabel 3. Aktifitas Anti Bakteri pada Asap Cair Cangkang Kelapa Sawit

\begin{tabular}{|c|c|c|c|c|}
\hline \multirow{2}{*}{ No. } & \multirow{2}{*}{ Perlakuan } & \multicolumn{4}{|c|}{ Daerah zona penghambatan } \\
\cline { 3 - 5 } & E.coli $(\mathrm{cm})$ & Salmonella $(\mathrm{cm})$ & S. aureus $(\mathrm{cm})$ \\
\hline 1 & A & 1,5 & $\begin{array}{c}\text { Tidak ada } \\
\text { penghambatan }\end{array}$ & 1,5 \\
\hline 2 & B & 1,5 & $\begin{array}{c}\text { Tidak ada } \\
\text { penghambatan }\end{array}$ & 1,5 \\
\hline 3 & C & $\begin{array}{c}\text { Tidak ada } \\
\text { penghambatan }\end{array}$ & $\begin{array}{c}\text { Tida } \\
\text { penghambatan }\end{array}$ & $\begin{array}{c}\text { Tidak ada } \\
\text { penghambatan }\end{array}$ \\
\hline
\end{tabular}

Keterangan :

$A=$ Asap cair tanpa pemurnian,

$B=$ Asap cair murni perkaluan pengendapan-penyaringan,

$C=$ Asap cair mumi perlakuan penyulingan.

\section{KESIMPULAN}

Asap cair murni yang dihasilkan dengan cara penyulingan mempunyai sifat fisik paling jernih, kadar kotoran $0,09 \%$ dan $\mathrm{pH} 3,07$. Senyawa kimia dominan yang keberadaannya selalu ada pada ketiga perlakuan yaitu yang tidak dimurnikan dan yang dimurnikan dengan pengendapan-penyaringan serta dimurnikan dengan penyulingan adalah cyclopentanone, 2furancarboksaldehide, asam asetat dan asam propanoat.

Asap cair yang tidak dimurnikan dan yang dimurnikan dengan pengendapan-penyaringan memiliki daya hambat yang cukup kuat terhadap pertumbuhan bakteri $E$. coli dan $S$. aureus tetapi tidak dapat menghambat pertumbuhan Salmonella, sedangkan yang dimurnikan melalui proses penyulingan tidak memiliki daya hambat terhadap pertumbuhan $E$. coli, $S$. aureus dan Salmonela.
Untuk keperluan pengawetan pangan dianjurkan menggunakan asap cair yang telah dimurnikan dengan proses pengendapan-penyaringan, disamping dapat mengontrol pertumbuhan mikroba, juga sifat fisiknya lebih baik dan juga tidak akan mempengaruhi penampilan bahan pangan yang diawetkan.

\section{DAFTAR PUSTAKA}

Arviza $Y$ dan Amin S.2006. Mukjizat Asap dari Kulonprogo, Tempo edisi 22 Januari 2006, halaman 56-57.

Girard, JP. 1992. Smoking dalam " Technology of Meat and Meat Product". Ellis Horwood New York.

Hadiwiyoto, S., Darmadji, P., dan Purwasari, SR. 2000. Perbandingan Pengasapan Panas Dan Penggunaan Asap Cair Pada 
Pengolahan Ikan; Tinjauan Kandungan Benzopirin, Fenol dan Sifat Organoleptik Ikan Asap. Agritech, Fakultas Teknologi Pertanian, Universitas Gajah Mada, Yogyakarta.

Ita Zuraida. 2009. Daya Hambat Asap CairTempurung Kelapa Terhadap Bakteri Patogen. Jurnal Teknologi Pertanian, Universitas Mulawarman, Vol 4 No 2, Maret 2009 hal 56-62.

Lewis, RJ., 1993. Hawley's Condensed Chemical Dictionary, Van Nostrand Reinhold Company, New York.

Marpaung, DS. 2009. Pemanfaatan Limbah Pabrik Kelapa Sawit Sebagai Pembangkit Listrik. http:// Dedy Suhendra Marpaung. Blok,spot.com, Oktober, 2009

Pszczola. 1995. Tour Highlights Production and Uses of Smoke Base Flavors. Food Technology 49: $70-75$

Pujilestari, T. 2007. Pengaruh Cara Pemisahan Cuka Kayu Dari Asap Cair Kayu Galam Untuk Keperluan Industri Pengolahan Pangan. Departemen Perindustrian. Balai Riset dan Standardisasi Industri Banjarbaru.
Rahmi, N., dan Pujilestari, T. 2008. Aktivitas Anti Bakteri Dari Cuka Kayu Pohon Akasia, Karet dan Galam. Warta Balai Industri Banjarbaru. Vol XXIII. No 2, hal 21 -25. Balai Riset dan Standardisasi Industri Banjarbaru.

Tranggono, Suhardi, Setiadji, B., Darmadji P., Supranto, Sudarmanto, dan Armunanto, R., 1996. Adsorbsi Senyawa Komponen Asap Cair pada Zeolit. Makalah disampaikan pada Seminar Nasional Pangan dan Gizi dan Konggres PAPTI di Yogyakarta, 10 -11 Juli 1996.

-.-.-.-, Suhardi, dan Setiadji, B. 1997. Produksi Asap Cair dan Penggunaannya Pada Pengolahan Beberapa Bahan Makanan Khas Indonesia. Laporan Akhir Riset Unggulan Terpadu III. Kantor Menteri Negara Riset dan Teknologi. Proyek Puspitek. Yogyakarta

Yatagai, M. 2004. Utilization Of Charcoal And Wood Vinegar In Japan. Seminar on "Enhancing The Development And Wood Vinegar. Bogor. 